\title{
ASUPAN GULA HARIAN DARI BAHAN-BAHAN PELENGKAP MASAKAN
}

\author{
Evelyn Loanda ${ }^{1}$, Ay Ly Margaret ${ }^{1}$, Jenny Hidayat $^{1}$
}

\begin{abstract}
Abstrak
Asupan gula penting untuk dibatasi dalam diet sehari-hari. Hal ini dapat menjadi upaya preventif maupun terapi penyakit diabetes mellitus. Asupan gula tambahan maksimal yang dianjurkan per hari 24 gram. Gula yang berada dalam bahan-bahan pelengkap masakan seperti kecap manis, saos sambal, dan saos tiram selama ini tidak diperhitungkan sebagai asupan gula yang harus dibatasi. Peneliti berpendapat bahan-bahan pelengkap masakan tersebut berpengaruh terhadap asupan gula harian. Kuesioner dibagikan kepada 65 subjek penelitian secara random di RW 13 Perum Bumi Dirgantara. Data konsumsi bahan pelengkap masakan harian diperoleh dari hasil kuesioner tersebut. Peneliti juga mengambil 5 sampel dari masing-masing jenis bahan pelengkap masakan secara random. Kadar gula masing-masing sampel diukur dengan metode asam sulfat - UV spektrofotometri $315 \mathrm{~nm}$. Diperoleh hasil gula yang terdapat pada bahan pelengkap masakan per sendok teh adalah sebagai berikut saos tomat $(0,58 \mathrm{gram})$, saos sambal (0,74 gram), saos tiram ( 0,85 gram), kecap manis (0,88 gram). Konsumsi gula dari bahan pelengkap masakan rata-rata per hari sebesar 0,1354 gram. Jumlah gula dari bahan pelengkap masakan tidak berperan besar dalam peningkatan asupan gula harian. Bagaimanapun konsumsi bahan makanan pelengkap masakan secara berlebihan tidak direkomendasikan.
\end{abstract}

Kata Kunci: gula, asupan gula harian, pelengkap masakan, diabetes

\section{Abstract}

Restriction sugar intake is very important in daily diet. Reducing sugar intake can become preventive or therapeutic management for diabetes mellitus. Maximum Reference Daily Intake for sugar is 24 gram. Sugar in food seasoning product wasn't considered in glucose intake. We suggest that seasoning products have big contribution in daily sugar intake. Questionaire was given to 65 research subject randomly in RW 13 Perum Bumi Dirgantara. We got food seasoning consumpsion data from the questionaire. Five sample from each kind seasoning consumption had been taken from research subject randomly, three sample for each kind used for analysis. Sugar from each sample was measured with sulfuric acid UVSpectrophotometri. The result were sugar in one tea spoon seasoning was 0.58 gram in tomato sauce, 0.74 gram for chilli sauce; 0.85 gram for oyster sauce and 0.88 gram in sweet soya bean sausage. Rate of sugar consumtion from seasoning product was 0.1354 gram daily. Sugar intake from food seasoning products didn't give big contribution to increase daily sugar intake. However consumption of excessive amount of food seasoning products is not recommended.

Key words: sugar, daily sugar intake, food seasoning, diabetes

Afiliasi Penulis: 1. Departemen Biokimia-Kimia, Fakultas Kedokteran Universitas Katolik Indonesia Atma Jaya. Korespondensi: Evelyn Loanda, email: evelovechocolate@gmail.com. 


\section{PENDAHULUAN}

Diabetes melitus (DM) adalah gangguan metabolisme yang ditandai dengan peningkatan gula darah yang kronis akibat berkurangnya sekresi insulin atau kerja insulin atau keduanya. ${ }^{1,2}$ Data yang dikeluarkan oleh International Diabetes Federation (2014) menyatakan prevalensi DM kurang lebih sekitar 382 juta orang pada populasi umur 2079 tahun dan jumlahnya akan meningkat menjadi 592 juta orang pada tahun 2035 di seluruh dunia. Berdasarkan data Riskesdas 2014, prevalensi DM di Indonesia pada tahun 2007 adalah 1,1\% dan meningkat menjadi 2,1\% pada tahun 2013. ${ }^{3}$ Pada penelitian yang dilakukan oleh Riskesdas tersebut, dilakukan dari wawancara dan pemeriksaan gula darah pada penduduk usia 15 tahun ke atas. Ada beberapa faktor risiko yang dapat meningkatkan kemungkinan terjadinya diabetes. Faktor risiko ini terbagi menjadi faktor risiko yang dapat dimodifikasi dan faktor risiko yang tidak dapat dimodifikasi. Faktor risiko yang tidak dapat dimodifikasi berupa ras, genetik, usia jenis kelamin, sedangkan faktor risiko yang dapat dimodifikasi berkaitan dengan gaya hidup, seperti kurangnya aktivitas fisik, pola makan yang tidak seimbang, obesitas, hipertensi, dislipidemia, dan merokok. ${ }^{2,3}$ Pencegahan diabetes dapat dilakukan terutama dengan mengendalikan faktor risiko yang dapat dimodifikasi khususnya untuk diabetes melitus tipe $2\left(D_{2}\right)^{3}$

$\mathrm{DM}_{2}$ dapat dicegah dan dikendalikan melalui perubahan gaya hidup seperti pengaturan pola makan dan peningkatan aktivitas fisik. ${ }^{4}$ Penderita DM yang terkontrol memiliki kualitas hidup yang lebih baik dibandingkan DM yang tidak terkontrol.
Hiperglikemia pada pasien DM disebabkan oleh defisiensi insulin ataupun aktivitas insulin yang menurun. Kondisi hiperglikemia yang kronik pada pada pasien DM memicu terbentuknya reaksi antara gula darah dengan protein plasma seperti albumin, fibrinogen, dan globulin secara non enzimatik. ${ }^{5}$ Proses ini dikenal dengan proses glikasi. Produk yang terbentuk berupa advanced glycation end product (AGE). AGE dapat menyebabkan gangguan dalam aktivasi platelet, pembentukkan radikal bebas, gangguan fibrinolisis, dan gangguan sistem imun. Glikasi pada kolagen dapat menyebabkan pembentukan ateroskerosis, fibrosis, dan penuaan kulit. $^{5}$ AGE yang terbentuk mendasari terjadinya komplikasi pada penderita DM, seperti retinopati, neuropati, nefropati, katarak, kardiomiopati, artritis reumatoid, osteoporosis, dan penuaan. $2,6,7$ Komplikasi penyakit $\mathrm{DM}_{2}$ dapat menurunkan kualitas hidup dan berdampak pada usia harapan hidup yang menurun. Penurunan kualitas hidup akan mempengaruhi produktivitas penduduk sehingga memberikan efek terhadap perekonomian suatu negara.

Menurut American Diabetes Association (ADA) tujuan dari terapi nutrisi pada penderita DM adalah mempertahankan kadar gula darah, kadar lipid, lipoporotein darah, tekanan darah dalam batas normal, meningkatkan kesehatan melalui pemilihan makanan yang tepat, dan aktivitas fisik dengan tetap menghargai selera dan kebudayaan penderita DM. ${ }^{8}$

Pengontrolan kadar gula darah dari penderita $\mathrm{DM}_{2}$ menjadi hal yang penting dalam mencegah terjadinya komplikasi $\mathrm{DM}_{2}{ }^{8,9,10}$ Pembatasan asupan karbohidrat memberikan efek yang paling besar dalam menurunkan kadar gula darah. ${ }^{10}$ Pengaturan 
pola makan dapat berupa pembatasan asupan bahan-bahan makanan yang memiliki kandungan karbohidrat yang tinggi. Bahanbahan pelengkap makanan yang sering digunakan dalam kehidupan sehari-hari seperti saos tomat, saos sambal, kecap manis, kecap asin, saos tiram, kecap inggris mengandung gula dalam kadar tertentu. Kandungan gula yang cukup tinggi pada bahan-bahan tersebut bertujuan untuk memperbaiki rasa dan juga sebagai pengawet alami. Tanpa disadari, kandungan karbohidrat yang berasal dari bahan-bahan tersebut di atas seringkali terabaikan dalam penghitungan kalori makanan. Padahal apabila dikonsumsi setiap hari, bahan-bahan ini berperan sebagai faktor predisposisi munculnya perburukan beberapa penyakit seperti hipertensi, maupun diabetes.

Total asupan karbohidrat harian yang dianjurkan untuk usia 30-49 tahun adalah 394 gram per hari untuk pria, sedangkan untuk wanita adalah 323 gram per hari. Angka asupan karbohidrat harian yang dianjurkan untuk usia 50-64 tahun adalah 309 gram untuk pria dan 285 gram untuk wanita. Asupan karbohidrat pada orang usia lanjut lebih dibatasi lagi menjadi 309 gram untuk pria dan 252 gram untuk wanita. ${ }^{11}$

Gula banyak digunakan sebagai pemanis untuk meningkatkan rasa dan mengawetkan makanan. ${ }^{12}$ Yang dimaksud dengan gula adalah monosakarida dan disakarida Konsumsi gula yang terdapat dalam bahan tambahan (added sugar, $A S$ ) dianjurkan tidak lebih dari 24 gram per hari untuk orang dengan kebutuhan kalori 1600 kalori per hari. ${ }^{12}$ Johnson dkk (2009) menyatakan Added sugar (AS) tidak lebih dari 25 gram/hari atau sekitar 100 kalori untuk wanita, dan tidak lebih dari 37,5 gram/hari atau sekitar 150 kalori untuk pria. ${ }^{13}$ Added sugar (AS) merupakan gula yang ditambahkan ke dalam bahan makanan selama proses pengolahan makanan. AS dapat ditemui pada minuman kaleng, kue, permen, dan bahan pelengkap makanan yang ditambahkan dalam proses memasak makanan sehari-hari.

Ketersediaan bahan pelengkap makanan yang beraneka ragam serta kemudahan dalam memperoleh bahan pelengkap makanan tersebut mendasari keingintahuan peneliti untuk melakukan studi terhadap kadar gula yang terkandung dalam bahan-bahan pelengkap makanan yang digunakan dalam rumah tangga. Hasil penelitian diharapkan dapat menjadi salah satu referensi dalam pengaturan diet bahan pelengkap makanan sehari-hari pada masyarakat, khususnya pada penderita DM.

\section{METODE}

\section{Pembagian Kuesioner}

Kuesioner mengenai pola makan bahan pelengkap masakan yang dikonsumsi selama 5 hari dibagikan kepada kader RW 13 Perum Bumi Bekasi, untuk disebarkan kepada 65 warga RW 13 Perum Bumi, Bekasi secara random. Setiap kuesioner dilengkap dengan satu sendok teh, untuk menyamakan persepsi subjek penelitian.

\section{Pengambilan Sampel Bahan Pelengkap Masakan}

Setiap jenis bahan pelengkap masakan, dimasukkan ke delam wadah plastik dan disegel. Dari setiap jenis sampel akan diambil 5 sampel dari subjek penelitian yang berbeda secara random untuk dianalisis lebih lanjut menggunakan metode asam sulfat-UV spektrofotometri. 


\section{Analisis Kadar Gula Sampel}

Menggunakan metode asam sulfat-UV spektrofotometri. Sampel bahan pelengkap masakan yang digunakan adalah saos tomat, saos sambal. saos tiram dan kecap manis. Sampel saos tomat, saos sambal dan saos tiram diencerkan sampai mencapai konsentrasi 0,02 mg\%, sedangkan sampel kecap manis diencerkan sampai mencapai konsentrasi 0,01 mg\% agar tidak terlalu pekat dan masih dapat terukur pada spektrofotometer. Larutan sampel diambil sebanyak $1 \mathrm{~mL}$ lalu ditambahkan $3 \mathrm{~mL}$ asam sulfat pekat, dan dicampur. Sampel kemudian diletakkan di atas es selama 2 menit. Satu $\mathrm{mL}$ campuran dimasukkan ke dalam spektrofotometer (Thermoscientific) menggunakan kuvet sekali pakai, dan dibaca pada panjang gelombang $315 \mathrm{~nm}$. Masing-masing sampel diukur secara triplo.

\section{Metode Statistik}

Penelitian bersifat survei, hasil dari penelitian ini berupa kadar gula rata-rata yang dikonsumsi oleh para subjek penelitian, dan kandungan gula pada masing-masing sampel. Perbedaan kadar gula masing-masing sampel dianalisis dengan metode Anova one way.

\section{HASIL DAN PEMBAHASAN}

Pada penentuan konsentrasi gula sampel, terlebih dahulu dilakukan pengukuran terhadap gula standar, dengan hasil yang ditunjukkan oleh Tabel 1 dan Gambar 1. Kurva standar gula dapat digunakan apabila didapatkan nilai $R^{2}>0,9$. Pada penelitian ini didapatkan nilai $R^{2}=0,993$, maka kurva ini dapat dipakai.

Tabel 1. Absorbansi standard gula

\begin{tabular}{lllll}
\hline $\begin{array}{l}\text { Konsentrasi } \\
\text { gula }(\mathrm{mg} \%)\end{array}$ & Abs 1 & 2 & 3 & $\begin{array}{l}\text { Absorbansi } \\
\text { rata-rata }\end{array}$ \\
\hline 2 & 0.312 & 0.32 & 0.32 & 0.318 \\
1 & 0.178 & 0.17 & 0.15 & 0.165 \\
0.5 & 0.155 & 0.18 & 0.09 & 0.141 \\
0.25 & 0.047 & 0.09 & 0.06 & 0.064 \\
0.125 & 0.011 & 0.02 & 0.03 & 0.019 \\
\hline
\end{tabular}

Keterangan Abs = absorbansi pada $315 \mathrm{~nm}$

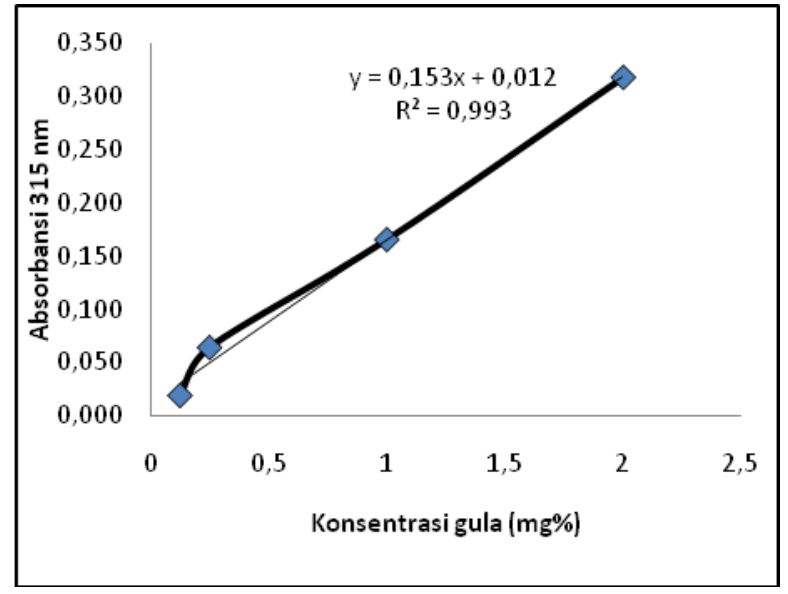

Gambar 1. Kurva standard gula

Analisa data kadar gula (Tabel 2) pada masing-masing jenis bahan pelengkap masakan menggunakan metode Shapiro-Wilk didapatkan berdistribusi normal dengan nilai $p=0,585(p>0,05)$. Kadar gula dari masingmasing jenis bahan pelengkap masakan tidak berbeda bermakna apabila dianalisis secara

Tabel 2. Konsentrasi gula per sendok teh sampel

\begin{tabular}{lccrrrr}
\hline Sampel & A & \multicolumn{1}{l}{ B } & C & Rata-rata & SD & SEM \\
\hline Saos tomat & 0.552 & 0.529 & 0.658 & 0.580 & 0.068 & 0.04 \\
Sambal & 0.411 & 1.109 & 0.702 & 0.741 & 0.35 & 0.206 \\
Saos tiram & 0.826 & 0.843 & 0.872 & 0.847 & 0.023 & 0.137 \\
Kecap manis & 0.553 & 1.028 & 1.047 & 0.876 & 0.279 & 0.164 \\
\hline
\end{tabular}


statistik dengan metode anova one way dengan nilai $p=0,424(p>0,05)$. Kadar gula dari masing-masing bahan pelengkap masakan dapat dilihat pada Gambar 2.

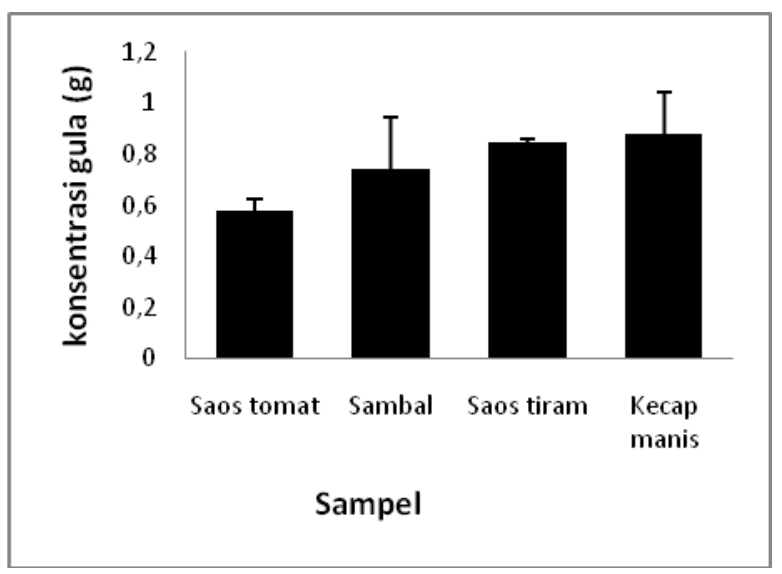

Gambar 2. Konsentrasi gula dalam tiap sendok teh

Berdasarkan kuesioner, konsumsi gula rata-rata yang berasal dari bahan pelengkap masakan 0,1354 gram per hari, dengan standard deviasi 0,034 (Tabel 3).

Tabel 3. Konsumsi gula dari pelengkap masakan per hari

\begin{tabular}{lccc}
\hline \multicolumn{2}{l}{$\begin{array}{l}\text { Konsumsi gula dari bahan } \\
\text { pelengkap masakan per hari }\end{array}$} & & \\
(g) & SD & SEM \\
\hline & 0.1354 & 0.034 & 0.004 \\
\hline
\end{tabular}

Dari hasil kuesioner dan pengambilan sampel secara random, maka didapatkan konsumsi gula yang berasal dari bahan pelengkap makanan rata-rata dari 65 subjek penelitian sebesar 0,1354 gram per hari. Jumlah ini jauh lebih kecil dibandingkan asupan gula tambahan (AS) yang diperbolehkan dalam bahan tambahan makanan, yakni sebesar 24 gram per hari. ${ }^{8}$ Namun demikian, tetap harus diperhatikan konsumsi dari bahan tambahan makanan yang ditambahkan secara pribadi setelah masakan disajikan di piring masing-masing. Pemakaian satu sendok teh saos tomat mengandung 0,58 gram AS, apabila seseorang mengkonsumsi saos tomat sebanyak 3-4 sendok teh per hari sudah menambahkan sekitar 2 gram AS dalam konsumsi sehari-hari. Konsumsi AS dalam bahan pelengkap masakan yang rendah pada penelitian ini, kemungkinan karena subjek penelitian tidak banyak menggunakan bahan pelengkap masakan yang diuji untuk mengolah makanan yang dikonsumsi sehari-hari. Selain itu juga didapatkan kesulitan mengukur jumlah bahan pelengkap masakan yang berasal dari makanan yang dikonsumsi di luar rumah. Hal ini didasarkan pada pertimbangan bahwa seringnya mengkonsumsi makanan seperti fast food, bakso, mie ayam di luar rumah umumnya menggunakanbahan pelengkap masakan seperti saos tomat, sambal, kecap manis yang ditambahkan secara individu pada makanan masing-masing.

Pada berbagai jenis sampel yang diteliti (saos tomat, saos sambal, saos tiram dan kecap manis) tidak ada perbedaan jumlah kandungan gula yang bermakna. Pada saos tomat, saos sambal, saos tiram, dan kecap manis memiliki jumlah AS yang sama dalam tiap sendok takarnya. Walaupun saos tomat, saos sambal, dan saos tiram tidak semanis kecap manis, komposisi bahan-bahan ini tetap mengandung AS. AS yang terkandung berfungsi untuk memperkuat cita rasa dan sebagai pengawet pada bahan-bahan pelengkap masakan tersebut.

Menurut penelitian oleh Sanjay dkk tahun 2016, asupan gula berhubungan dengan terjadinya diabetes tipe dua, pada penelitian mereka setiap penambahan 150 kalori gula (37,5 gram) per orang per hari berhubungan dengan peningkatan prevalensi diabetes sebesar $1,1 \%$. Mereka menyatakan bahwa paparan gula tinggi dalam waktu lama akan meningkatkan prevalensi diabetes. ${ }^{14}$ Bahaya dari konsumsi gula yang tinggi juga 
ditimbulkan akibat pembentukkan radikal bebas melalui reaksi Mailard dalam tubuh kita. ${ }^{5}$ Tinjauan lain yang dilakukan oleh Malik dkk, tahun 2013 menunjukkan konsumsi gula dalam minuman-minuman ringan dengan mendorong peningkatan berat badan baik pada dewasa maupun anak-anak. ${ }^{15}$ Resiko diabetes meningkat sejalan dengan peningkatan berat badan. Konsumsi gula yang berlebihan berkontribusi terhadap peningkatan berat badan dan resiko diabetes. ${ }^{16,17,18}$

Tinjauan lain menunjukkan hasil sebaliknya dilakukan oleh Rippe JM dan Angelopoulous TJ yang dipublikasi pada tahun 2016 bahwa gula yang terdapat pada bahan makanan tambahan tidak meningkatkan risiko diabetes, obesitas, maupun penyakit kardiovaskular apabila dikonsumsi dalam jumlah yang normal (maksimal 30\% kebutuhan kalori harian) asalkan AS tersebut menggantikan karbohidrat lain secara isokalori. ${ }^{19}$ Namun demikian perlu diperhatikan bahwa AS bisa didapatkan bukan hanya dari bahan pelengkap masakan, tetapi juga cemilan sehari-hari, seperti minuman ringan, kue-kue, coklat, es krim, permen, kopi instant, minuman kotak, juice dan minuman sachet yang mengandung gula lebih tinggi. Pada beberapa penelitian, minuman ringan menunjukkan hubungan bermakna dengan tingginya prevalensi $\mathrm{DM}_{2}$ dan sindroma metabolik. ${ }^{20}$ Pembatasan asupan gula untuk penderita DM dapat diarahkan pada makanan lain selain bahan pelengkap masakan.

\section{DAFTAR RUJUKAN}

1. American Diabetes Association, Diagnosis and classification of diabetes mellitus. Diabetes care. 2014;37(suppl1):81-9.
Beberapa penelitian menunjukkan konsumsi gula meningkat pada beberapa negara di dunia, sejalan dengan peningkatan diabetes ${ }^{14,22}$, tetapi pada negara Amerika Serikat, Australia dan Inggris konsumsi gula menurun, tetapi prevalensi diabetes tetap meningkat. ${ }^{21}$ Jadi ada faktor-faktor lain selain gula yang dapat meningkatkan resiko terjadinya diabetes, seperti total kalori yang dikonsumsi, gaya hidup yang kurang aktif, dan genetik. ${ }^{2,3}$ Jumlah kalori yang dibutuhkan oleh setiap orang berbeda-beda. Masyarakat perlu diberikan pengetahuan mengenai kebutuhan kalori mereka. Kebutuhan kalori harian dipengaruhi oleh jenis kelamin, berat badan, aktivitas fisik. ${ }^{23}$ Seseorang yang mengkonsumsi lebih banyak perlu melakukan aktivitas lebih. Pencegahan dan pengobatan penyakit diabetes tidak cukup dengan pembatasan asupan gula saja, tetapi perlu menerapkan gaya hidup sehat dan aktif.

\section{SIMPULAN}

Bahan-bahan pelengkap masakan tidak memiliki pengaruh besar terhadap asupan gula harian. Bahan-bahan ini memiliki kontribusi sekitar 0,58-0,87 gram gula setiap sendok teh. Meskipun demikian pemakaian bahan-bahan ini tetap perlu diperhatikan pada pasien DM dan orang-orang yang memiliki faktor resiko tinggi terhadap DM.

2. Murad MA, Abdulmageed SS, Iftikhar R, Sagga B. Assessment of the common risk factors associated with type 2 diabetes mellitus in Jeddah. Int J Endocrinol. 2014:616145. doi: $10.1155 / 2014 / 616145$. 
3. Badan penelitian kesehatan kementrian kesehatan RI. Riset Kesehatan Dasar. Jakarta: Dinas Kesehatan Republik Indonesia; 2013.

4. Magliano DJ, Barr ELM, Zimmet PZ, Cameron AJ, Dunstan DW, Colagiuri S. Glucose indices, health behaviors, and incidence of diabetes in Australia. Diabetes Care. 2008;31(2):267-72.

5. Singh VP, Bali A, Singh N, Jaggi AS. Advanced glycation end products and diabetic complications. Korean J Physiol Pharmacol. 2014;18(1):1-14

6. Gregg EW, Li YF, Wang J, Burrows NR, Ali MK, Rolka D, et al. Changes in diabetes related complications in the United States, 1990-2010. NEJM. 2014;370(16):1514-23.

7. Vijayaraghavan K. Treatment of dyslipidemia in patients with type 2 diabetes. Lipids Health Dis. 2010;9:144.

8. Franz MJ, Bantle JP, Beeb CA, Brunzell JD, Chiasson JL, Garg A, et al.. Nutrition Principles and Recommendations in Diabetes. ADA. 2004;27(1):S36-S46.

9. Solano M, Golberg R. Lipid management in Type 1 diabetes. 2006;24(1):27-32.

10.Feinman RD, Pogozelski WK, Astrup A, Bernstein RK, Fine EJ, Westman EC, et al. Dietary carbohydrate restriction as the first approach in diabetes management: Critical review and evidence base. Nutrition. 2015; 31(1):1-13.

11.Badan Pengawas Obat dan Makanan. Mengenal Angka Kecukupan Gizi Bagi Bangsa Indonesia. InfoPOM. 2014;15(4):3-5.

12.Dietary carbohydrates : sugar and starches. In : Dietary reference intake. Washington. 2005;6:265-324.

13.Johnson RK, Appel LJ, Brands M, Howard BV, Lefevre M, Lustig RH, Sacks F, et al. Dietary sugars intake and cardiovascular health. Circulation. 2009;120(11):1011-20.

14.Basu S, Yoffe P, Hills N, Lustig RH. The relationship of sugar to population-level diabetes prevalence: an econometric analysis of repeated cross-sectional data. PLoS One. 2013;8(2):e57873.

15. Malik VS, Pan A, Willett WC, Hu FB. Sugarsweetened beverages and weight gain in children and adults:a systematic review and meta-analysis. Am J Clin Nutr. 2013;98:1084102.

16.Sonestedt E , Overby NC, Laaksonen DE, Birgisdottir BE. Does high sugar consumption exacerbate cardiometabolic risk factors and increase the risk of type 2 diabetes and cardiovascular disease? Food Nutr Res. 2012;56:19104.

17.Imamura F, O’Connor L, Ye Z, Mursu J, Hayashino Y, Bhupathiraju SN, Forouhi NG. Consumption of sugar sweetened beverages, artificially sweetened beverages, and fruit juice and incidence of type 2 diabetes: systematic review, meta-analysis, and estimation of population attributable fraction. BMJ. 2015;351:3576.

18. Nguyen NT, Nguyen XMT, Lane J, Wang P. Relationship between obesity and diabetes in a US adult population: Findings from the national health and nutrition examination survey, 1999-2006. Obes Surg. 2011;21(3):351-5.

19.Rippe JM, Angelopoulos TJ. Added sugar and risk factors for obesity, diabetes and heart disease. Int J Obesity. 2016; 40(1):S22-7.

20.Malik VS, Popkin BM, Bray GA, Despres JP, Willet WC, Hu FB. Sugar-sweetened beverages and risk of metabolic syndrome and type 2 diabetes. Diabetes Care. 2010;30(11):2477-83.

21.Rippe JM, Angelopoulos T. Sugar and health controversies: What does the science say. Adv Nutr.2015;6(Suppl):493S-503S.

22.Goran MI, Ulijaszek SJ, Ventura EE. High fructose corn syrup and diabetes prevalence. A global perspective. Glob. Public Health 2013;8:55-64.

23. Report of Dietary Guidelines Advisory Committee on the for Americans. US Department of Agriculture, Center for Nutrition Polic and Promotion, Washington, DC, USA; 2010 